\title{
The Characteristics of Ground Motions Caused by Blasting in the Peikang Area
}

\author{
KUO-LIANG WEN \\ AND \\ YEONG-TEIN YEH \\ Institute of Earth Sciences \\ Academia Sinica, Taipei, Taiwan, R.O.C. \\ (Received 28 April 1990; revised 28 June 1990)
}

\begin{abstract}
In recent years, the problem of the effects of ground vibration generated by blasting on nearby structures has received a lot of attention. To minimize or eliminate damages, we need a reliable basis on which to plan and conduct blasting operations. For this reason, we performed seven experiments in the Peikang area. The observed peak ground motion values for different weights of explosive and source-receiver distances were used to obtain the following attenuation equations:

Acceleration $\left.(\mathrm{cm} \mathrm{sec})^{-2}\right): A=6.1476 R^{-1.6263} W^{1.0375}$,

Velocity $\left(\mathrm{mm} \mathrm{sec}^{-1}\right): \quad V=3.5315 R^{-1.2664} W^{0.7836}$,

where $W$ represents the weight of explosive in $g m$, and $R$ is the sourcereceiver distance in meters.

Additionally, the ground acceleration time histories of the test were transferred to a frequency domain to study their contents. From the spectra, we realize that the dominant frequency band of the Peikang area is lower than $10 \mathrm{~Hz}$. There is also a second energy concentration in the $15-30 \mathrm{~Hz}$ band. The particle motions indicated that the high frequency vibration (larger than $15 \mathrm{~Hz}$ ) is a body wave which came from the blast'source and the low frequency vibration (lower than 10 $H z$ ) is mainly a surface wave contribution which was generated by the local geological structure.
\end{abstract}

\section{INTRODUCTION}

The relationship between blasting operations and building damage is often a subject of argument when blasting is done in the vicinity of buildings. Until recently, however, there has been a dearth of published information relating blasting conditions to reliably documented damage in the Taiwan area. Engineers must, however, be able to determine the maximum weight of explosive that can be detonated without damaging adjacent structures. 
In June 1985, an explosive survey in the Peikang area was performed by the Institute of Earth Sciences, Academia Sinica and the Chinese Petroleum Corporation. In our study, a dynamite source was used and recordings were obtained at different hypocentral distances. The seismograms were analyzed to show the characteristics of the ground motion over time and the frequency domain. Finally, the relationships between ground motions, distances, and amount of dynamite are inferred for the Peikang area. Hopefully, our results will benefit the engineering community.

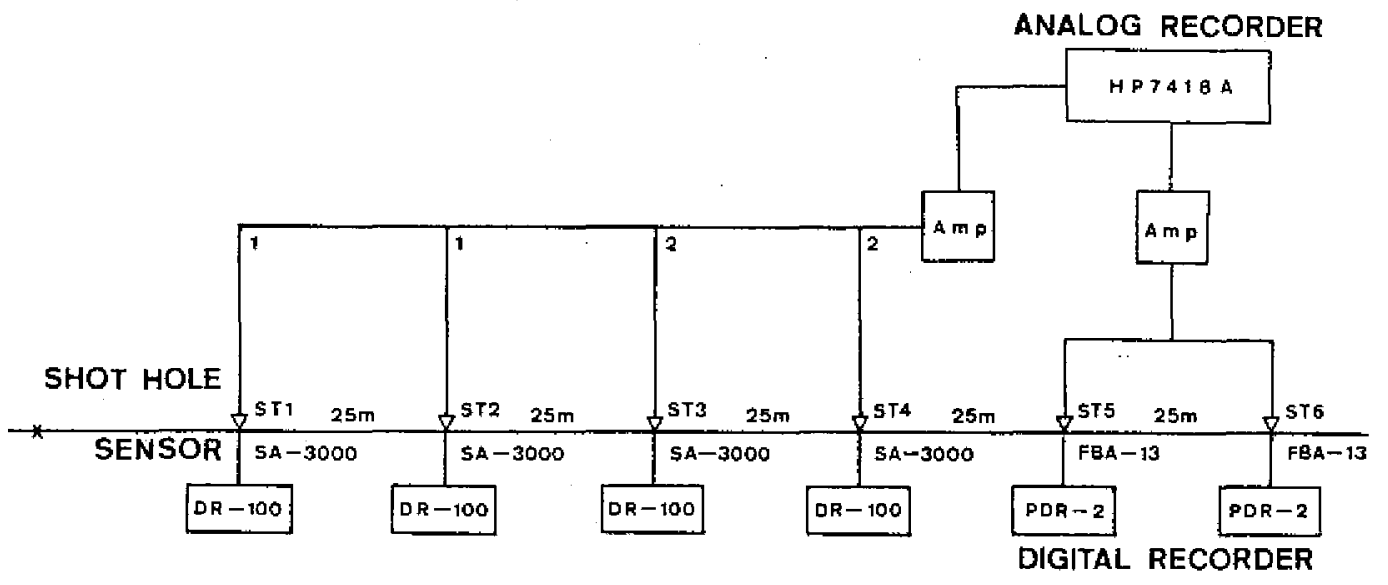

Fig. 1. Seismic survey system in this study.

\section{FIELD OPERATION}

In June 1985, we conducted a test in the Peikang area in central Taiwan. The observation system (Fig. 1) was composed of four SA-3000 accelerometers and DR-100 digital recorders from the Sprengnether Corporation and two FBA-13 accelerometers and PDR-2 digital recorders from the Kinemetrics Corporation. Both SA-3000 and FBA-13 accelerometers have three components. The arrangements of the two horizontal components are, respectively, parallel $(\mathrm{L})$ and transverse $(\mathrm{T})$ to the survey line. Totally, there were 18 channels for digital recording. The sampling interval for each channel is 0.01 seconds. At the same time, an analog recorder of HP7418A was used to monitor the experiment.

There were seven shots conducted in the Peikang area. Every shot hole did not have an iron casing. Table 1 illustrates the pertinent information about shot holes, weight of the explosive and the distance between the middle shot hole and the farthest station for each blast. The positions of the receivers were fixed, but the shot points were shifted to the west or northwest direction along the survey line. 
Table 1. Field surveys in the Peikang area.

\begin{tabular}{|c|c|c|c|c|}
\hline Shot NC. & $\begin{array}{l}\text { Arrangement }{ }^{2} \& \text { depth } \\
(\mathrm{m}) \text { of shot hole }\end{array}$ & $\begin{array}{c}\text { Charge weight } \\
(\mathrm{kg})\end{array}$ & $\underset{(\mathrm{m})}{\text { Distance }}$ & Remark \\
\hline 1 & 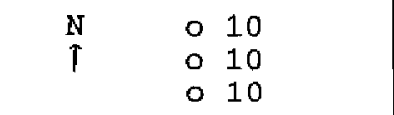 & $2 \times 3$ & 150 & \\
\hline 2 & $\begin{array}{rrrr}N & 0 & 0 & 0 \\
\uparrow & 10 & 10 & 10\end{array}$ & $2 \times 3$ & 250 & \\
\hline .3 & $\begin{array}{rrrr}N & 0 & 0 & 0 \\
T & 10 & 10 & 10\end{array}$ & $3 \times 3$ & 300 & \\
\hline 4 & $\begin{array}{rrrr}N & 0 & 0 & 0 \\
\uparrow & 10 & 10 & 10\end{array}$ & $2 \times 3$ & 150 & \\
\hline 5 & $\begin{array}{rrrr}N & 0 & 0 & 0 \\
\dagger & 10 & 10 & 10\end{array}$ & $3 \times 3$ & 350 & \\
\hline 6 & $\begin{array}{rrrr}N & 0 & 0 & 0 \\
\uparrow & 10 & 10 & 10\end{array}$ & $1 \times 3$ & 150 & $\begin{array}{l}\text { shot hole shift } \\
8 \text { m to the north }\end{array}$ \\
\hline 7 & $\begin{array}{llll}N & 0 & 0 & 0 \\
1 & 5 & 5 & 5\end{array}$ & $1 \times 3$ & 150 & $\begin{array}{l}\text { shot hole shift } \\
16 \mathrm{~m} \text { to the north }\end{array}$ \\
\hline
\end{tabular}

Note: 1. Shot hole interval are fixed in 8 meters.

2. Distance between the farthest station and middle shot hole.

\section{THE GROUND MOTIONS}

Since field data were recorded on cassette tapes, they had to be played back and transferred to a 9-track tape first. The data were then edited to delete the occasional glitches. The baseline correction was also made at this stage. Figs. 2 and 3 plot some examples of the corrected acceleration time traces for two different charges. From these figures, we can see without difficulty that the ground motion attenuates with distance which occurs at a higher rate in the near field. Comparing the time histories of different charges (Figs. 2 and 3 ), we can also see that the ground motion is propotional to the weight of the explosive.

The waveforms had large low frequency ground rolling following the high frequency motions. The reason for this may be occurred by the underground geological structure and the properties of the strata in the survey area.

The peak ground acceleration and velocity are commonly used to represent the intensity of the ground motion for engineering design criteria. In this study, the acceleration was integrated in the frequency domain to compute the ground velocity records. From the recorded time histories, the largest peak acceleration or velocity of the three components was chosen for every site and tabulated in 


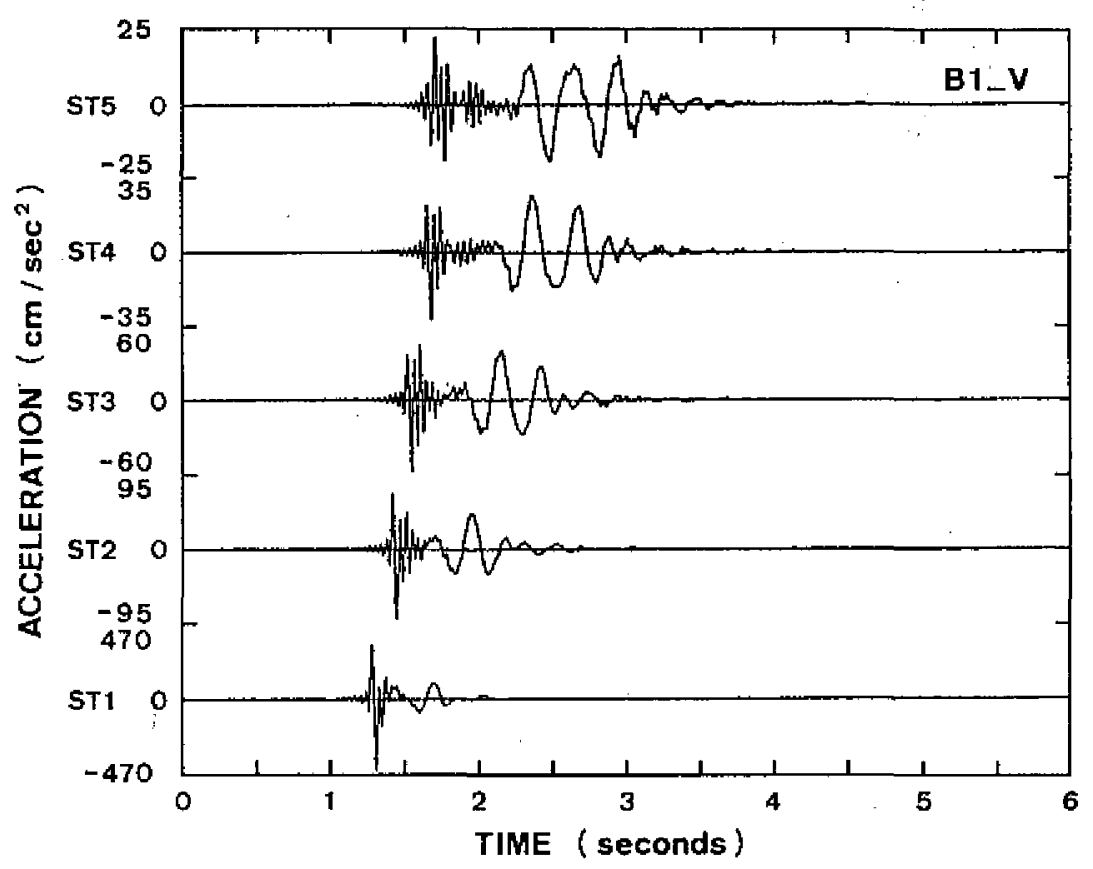

Fig. 2. Vertical acceleration waveforms for the first blast with $6 \mathrm{~kg}$ of dyramite in the Peikang area.

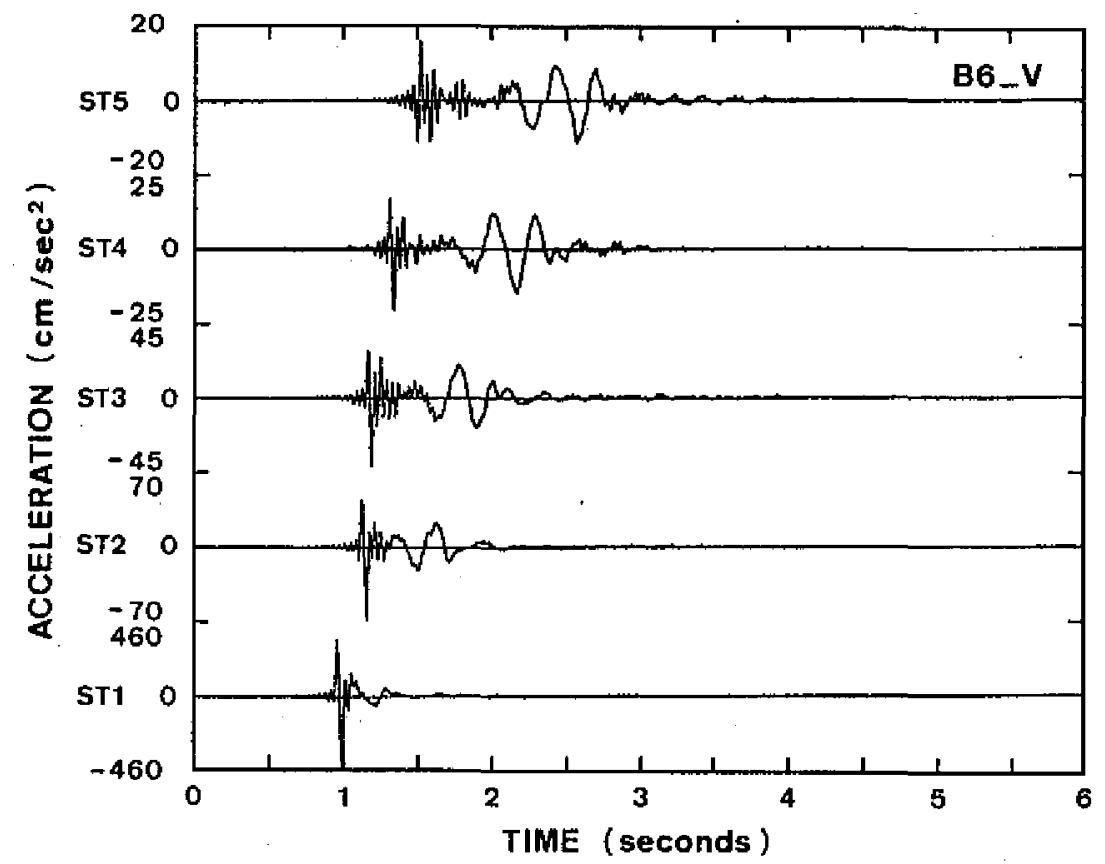

Fig. 3. Vertical acceleration waveforms for the sixth blast with $3 \mathrm{~kg}$ of dynamite in the Peikang area. 
Table 2. Peak ground motion of each site in the Peikang area.

\begin{tabular}{|c|c|c|c|c|c|c|c|c|}
\hline \multirow{2}{*}{\multicolumn{2}{|c|}{$\frac{\text { station }}{\text { Shot No. }}$}} & \multirow{2}{*}{ ST1 } & \multirow{2}{*}{$\mathrm{ST} 2$} & \multirow{2}{*}{ ST3 } & \multirow{2}{*}{ ST 4} & \multirow{2}{*}{ ST 5} & \multirow{2}{*}{ ST6 } & \multirow{2}{*}{$\begin{array}{c}\mathrm{W} \\
(\mathrm{kg})\end{array}$} \\
\hline & & & & & & & & \\
\hline \multirow{3}{*}{1} & Acc. & $470.55^{v}$ & $90.35^{v}$ & $58.28^{4}$ & $32.63^{v}$ & $23.09^{v}$ & $\longrightarrow$ & \multirow{3}{*}{6} \\
\hline & vel. & $70.57^{\mathrm{L}}$ & $17.48^{v}$ & $15.90^{v}$ & $11.46^{v}$ & $8.21^{v}$ & $\ldots$ & \\
\hline & Dis. & 26.93 & 50.99 & 75.66 & 100.50 & 125.40 & $\overline{ }$ & \\
\hline \multirow{3}{*}{2} & Acc. & $21.80^{v}$ & & - & $11.56^{\mathrm{V}}$ & $12.13^{v}$ & $7.78^{r}$ & \multirow{3}{*}{6} \\
\hline & vel. & $9.27^{\vee}$ & & - & $3.87^{\mathrm{L}}$ & $3.66^{\mathrm{L}}$ & $3.94^{2}$ & \\
\hline & Dis. & 117.43 & $\longrightarrow$ & - & 192.26 & 217.23 & 242.21 & \\
\hline \multirow{3}{*}{3} & Acc. & & & $14.97^{\vee}$ & $14.09 v$ & $20.40^{v}$ & & \multirow{3}{*}{9} \\
\hline & Vel. & $\longrightarrow$ & & $4.53^{\mathrm{V}}$ & $4.02^{v}$ & $3.99^{v}$ & $\bar{r}$ & \\
\hline & Dis. & $\longrightarrow$ & $\longrightarrow$ & 217.23 & 242.21 & 267.19 & $\longrightarrow$ & \\
\hline \multirow{3}{*}{4} & Acc. & $151.85^{L}$ & $77.33^{\vee}$ & $\longrightarrow$ & $28.66^{v}$ & $18.12^{v}$ & $6.74^{v}$ & \multirow{3}{*}{6} \\
\hline & vel. & $56.89 \mathrm{~L}$ & $14.10^{\mathrm{v}}$ & $\longrightarrow$ & $11.89^{v}$ & $8.72^{v}$ & $3.75^{\mathrm{v}}$ & \\
\hline & Dis. & 19.72 & 43.17 & & 92.54 & 117.43 & 142.35 & \\
\hline \multirow{3}{*}{5} & ACC. & & & $13.19^{\vee}$ & $14.78^{v}$ & $18.16^{v}$ & $3.17^{v}$ & \multirow{3}{*}{9} \\
\hline & Vel. & $\longrightarrow$ & $\longrightarrow$ & $3.09 \mathrm{~L}$ & $3.53^{v}$ & $3.38 v$ & $1.74^{v}$ & \\
\hline & Dis. & 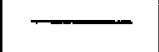 & & 267.19 & 292.17 & 317.16 & 342.15 & \\
\hline \multirow{3}{*}{6} & Acc. & $451.93^{v}$ & $69.13^{v}$ & $41.90^{\mathrm{V}}$ & $20.32^{v}$ & $16.30^{\mathrm{v}}$ & & \multirow{3}{*}{3} \\
\hline & vel. & $55.49^{\mathrm{r}}$ & $9.27^{v}$ & $9.04^{\mathrm{V}}$ & $6.02^{\mathrm{V}}$ & $4.70^{\circ}$ & $\longrightarrow$ & \\
\hline & Dis. & 21.28 & 43.91 & 68.21 & 92.89 & 117.70 & - & \\
\hline \multirow{3}{*}{7} & Acc. & $222.44^{v}$ & $32.25^{v}$ & $21.38^{v}$ & $17.67^{\mathrm{v}}$ & & $4.41^{v}$ & \multirow{3}{*}{3} \\
\hline & vel. & $38.34^{v}$ & $10.09^{v}$ & $9.51^{\mathrm{v}}$ & $7.00^{\mathrm{V}}$ & $\longrightarrow$ & $2.32^{v}$ & \\
\hline & Dis. & 23.87 & 45.22 & 69.07 & 93.51 & & 142.99 & \\
\hline
\end{tabular}

Note: 1. The unit of Dis. is in meters, Acc. is in gal, and vel. is in $\mathrm{mm} / \mathrm{sec}$.

2. $V$ and $L$ represent the peak occurred component.

Table 2. Most of the largest peak amplitudes in the Peikang area appear in the vertical (V) component.

\section{FREQUENCY CONTENTS}




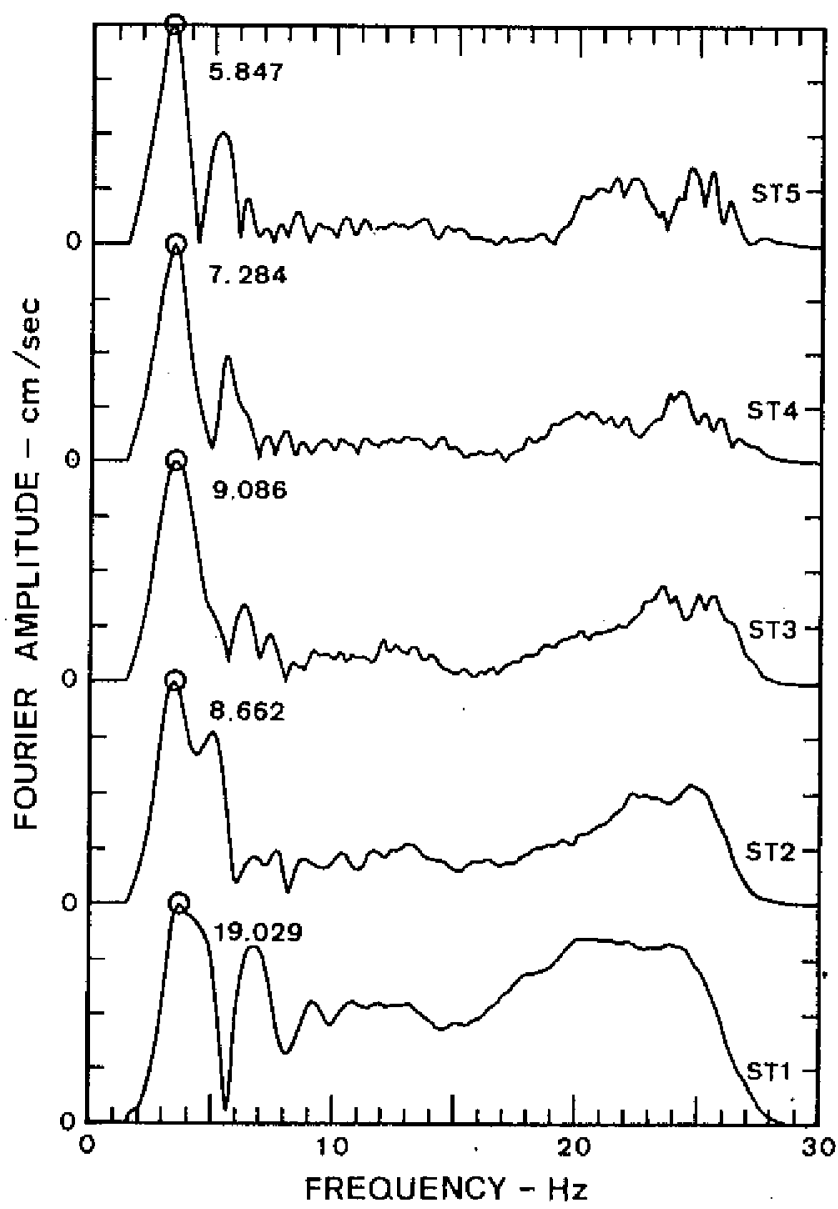

Fig. 4. Normalized Fourier spectra of the $\mathrm{V}$ component for the first blast in the Peikang area.

In this study of the vibration problem, frequency contents are a very important characteristic. Fourier spectra are very useful in determining the predominant frequencies, and in general, for studying the distribution of vibrational energy over the entire frequency range. A fast Fourier transformation (Cooley and Tukey, 1965) was used for calculating the amplitude spectra. A typical spectra is shown in Fig. 4, for the first blast of the survey. Each spectrum was normalized to its peak value. The dominant frequency band is lower than 10 $\mathrm{Hz}$. However, there was also a second energy concentration in the $15-30 \mathrm{~Hz}$ band:

For the sake of determining the characteristics of these two frequency bands, we used a band pass filter to split it. Fig. 5 is the time history lower than 10 $\mathrm{Hz}$, for the first blast. Fig. 6 is the time history larger than $15 \mathrm{~Hz}$, for the first blast. Comparing these with Fig. 2, we find that the low frequency 

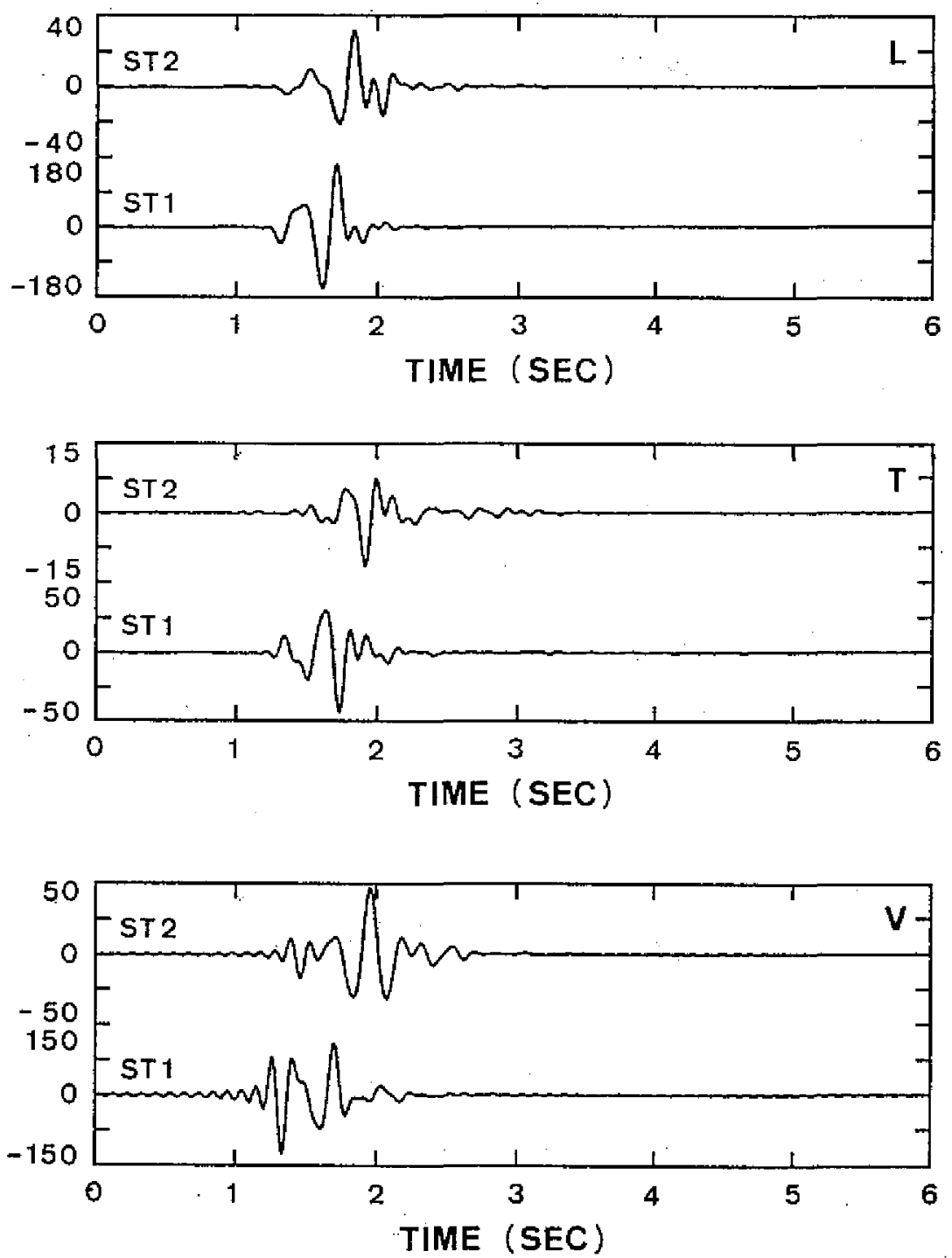

Fig. 5. Time histories of the low frequency $(<10 \mathrm{~Hz})$ band of stations 1 and 2 for the first blast in the Peikang area.

vibration occurred after the high frequency vibration. At the same time, we plotted out the particle motions of these two records on Figs. 7 and 8. The higher frequency (larger than $15 \mathrm{~Hz}$ ) band's particle motion was dominated by a vertical component (see Figs. $7 \mathrm{~b}$ and $8 \mathrm{~b}$ ); the lower frequency (lower than $10 \mathrm{~Hz}$ ) band's particle motion (see Figs. 7a and 8a) describes an ellipse, the motion being retrograde. Based on these particle motions, we can see that the high frequency vibrations are the body wave's motion which came from the source, and the low frequency vibration are the surface wave's motion which 

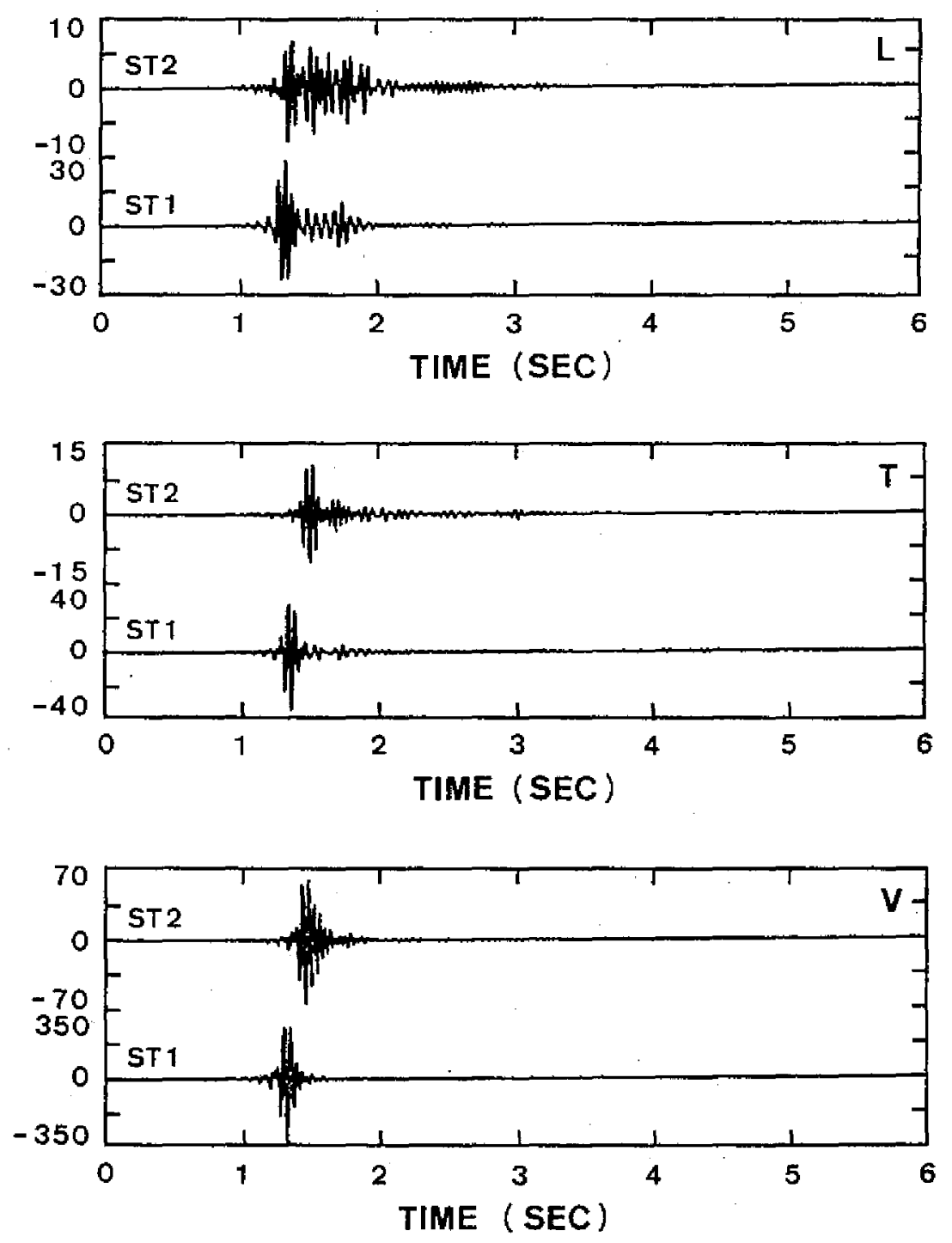

Fig. 6. Time histories of the high frequency $(>15 \mathrm{~Hz})$ band of stations 1 and 2 for the first blast in the Peikang area.

was generated by the local geological structure.

\section{ATTENUATION EQUATIONS}

The determination of the maximum safe explosive amount requires the knowledge of : 1. The attenuation equation of the ground motions resulting from blasting, whereby the intensity of ground vibration can be predicted on the basis of the weight of explosive, distance from the detonation point, and 


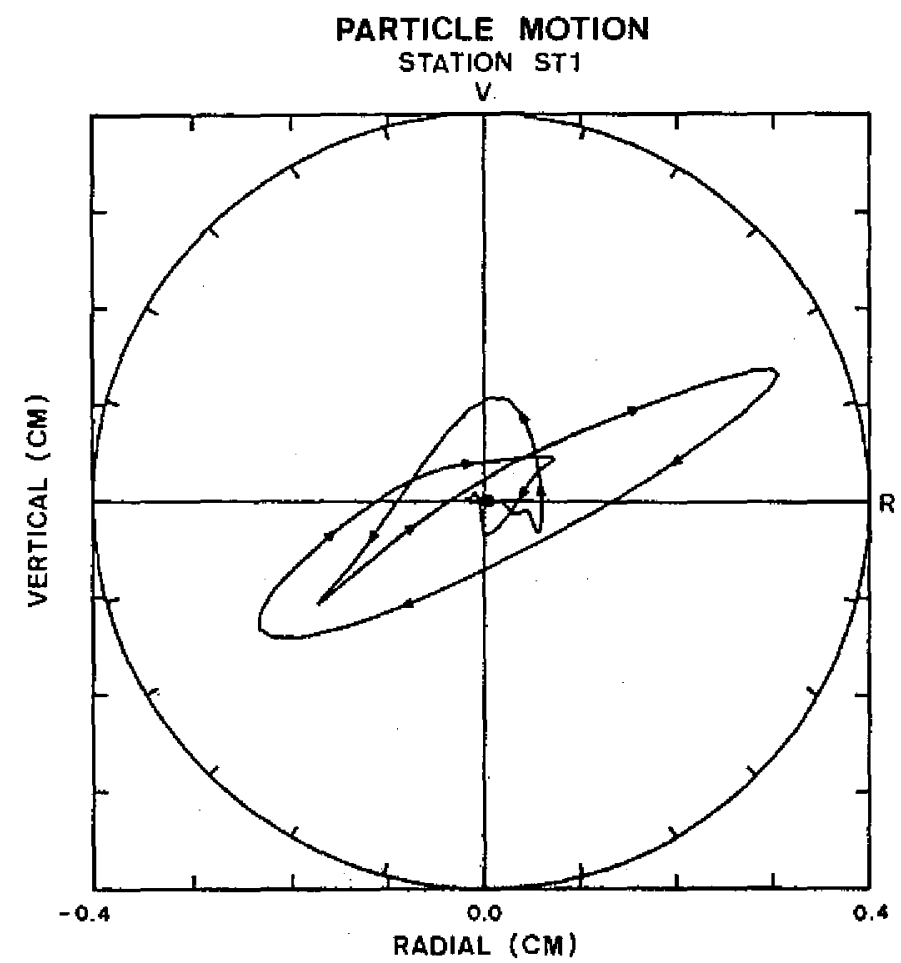

Fig. 7. (a) Particle motion of the low frequency $(<10 \mathrm{~Hz}$ ) band of station 1 for the first blast in the Peikang area.

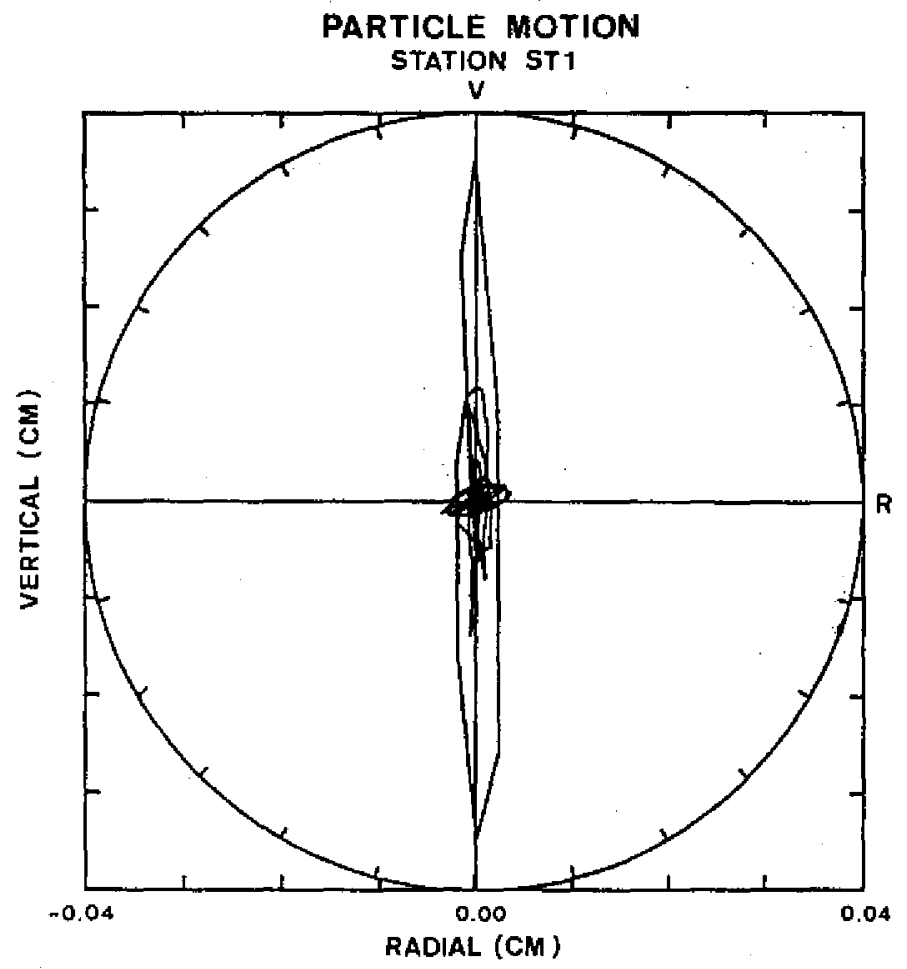

Fig. 7. (b) Particle motion of the high frequency ( $>15 H z$ ) band of station 1 for the first blast in the Peikang area. 


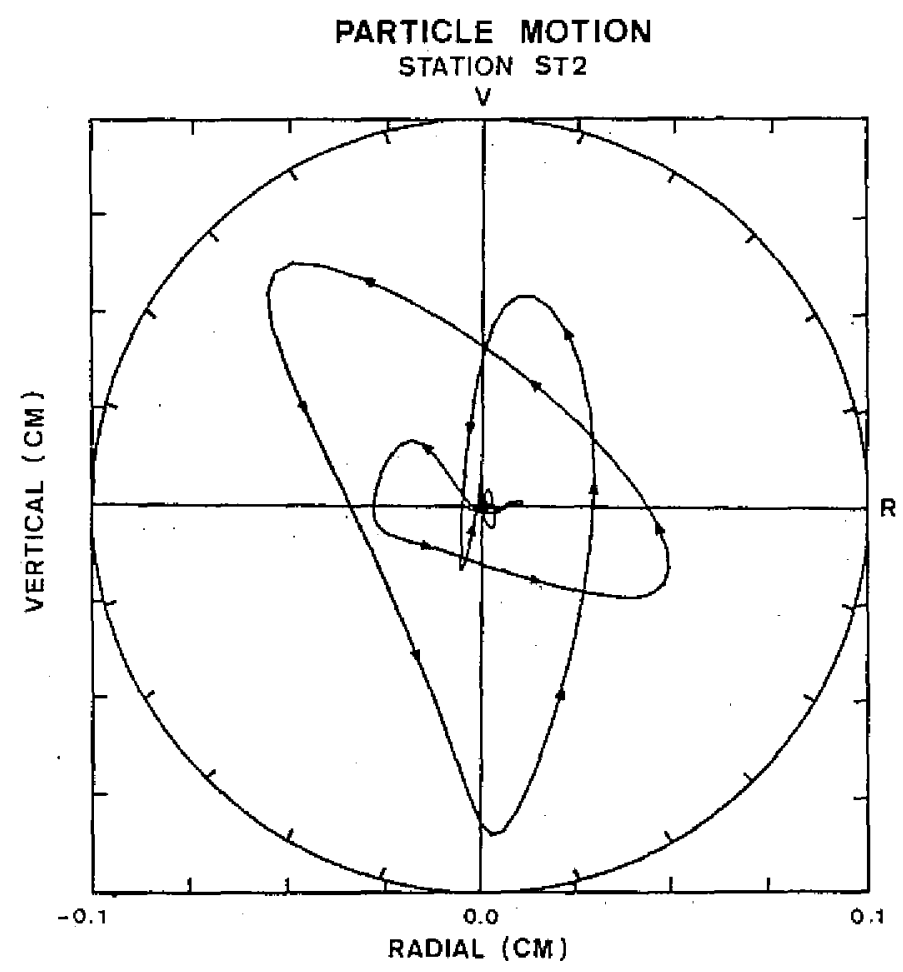

Fig. 8. (a) Particle motion of the low frequency $(<10 \mathrm{~Hz}$ ) band of station 2 for the first blast in the Peikang area.

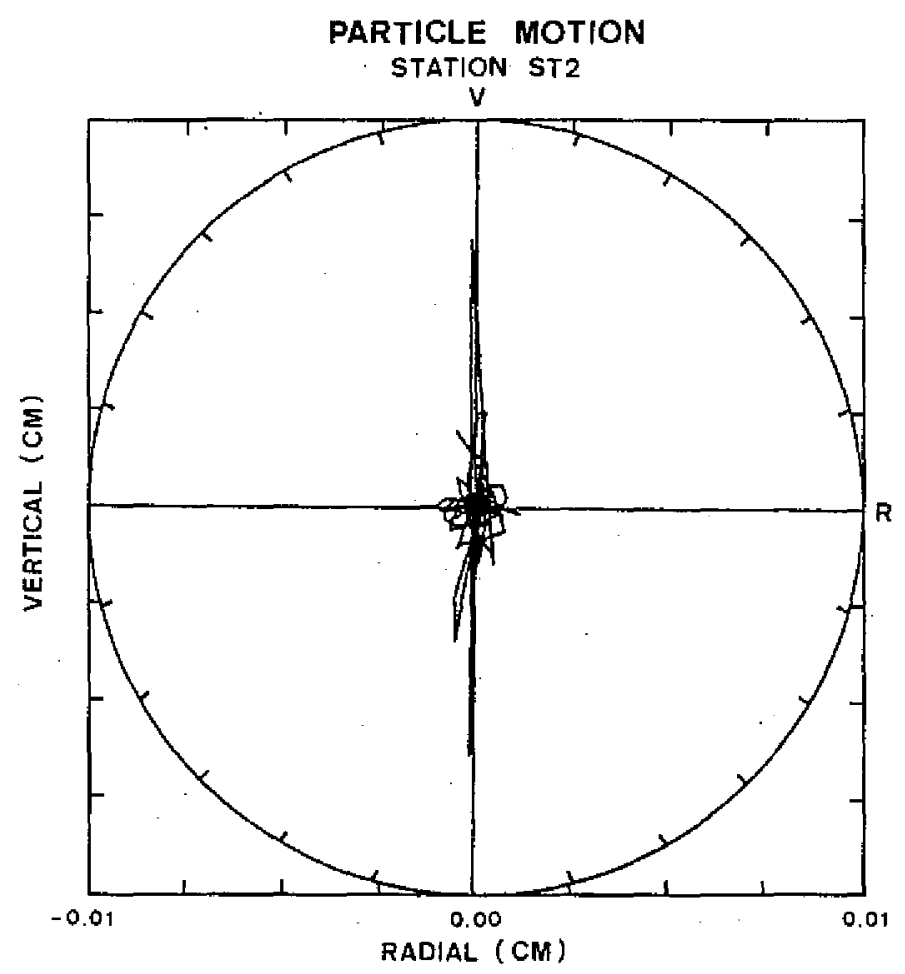

Fig. 8. (b) Particle motion of the high frequency $(>15 \mathrm{~Hz}$ ) band of station 2 for the first blast in the Peikang area. 
dynamic properties of soil and rock, etc. 2. Reliable damage criteria for different types of structures, whereby the damage of a structure can be correlated with the intensity of the ground vibration.

Since 1935, many investigations have been conducted to study the effects of ground vibrations on structures and to formulate the attenuation equation of ground vibrations (Duvall and Fogelson, 1962; Northwood et al., 1963; Naik, 1979; and Wiss, 1981). There is no universally accepted theoretical approach to derive the attenuation equation. Empirical approaches are presently used. The most widely accepted form is :

$$
Y=k R^{m} W^{n}
$$

where $Y$ is the peak amplitude of the vibration at a distance $R$ from the detonation of an explosive charge of weight $W$. The constant $k, m$ and $n$ are associated with the properties of the transmitting medium and other variables (Dowding, 1977; Medearis, 1977; Chae, 1978; Shigekazu Uchiyama et al., 1979).

If the attenuation equation of formula (1) is linear on a natural logirithm scale, then we can change it to :

$$
\ln Y=a+b \ln R+c \ln W
$$

where $a=\ln k, b=m$, and $c=n$. These constants $a, b$, and $c$ can be calculated by the multiple linear regression method (Ang and Tang, 1975). The results are as follows,

$$
\begin{aligned}
& \ln A=1.6763-1.5489 \ln R+1.0272 \ln W \pm 0.5034, \\
& \ln V=1.2225-1.2664 \ln R+0.7836 \ln W \pm 0.2757,
\end{aligned}
$$

where, $A$ is the peak ground acceleration in $\mathrm{cm} \mathrm{sec}^{-2}, V$ is the peak ground velocity in $m m \sec ^{-1}, R$ is the source-receiver distance in meters, and $W$ is the weight of explosive in $g m$.

If the uncertainties in. the data are small, a fit to equation (2) will yield a good fit to equation (1). The problem comes when trying to optimize the fit for reasonable uncertainties. In effect, the reparameterization of equation (2) overemphasizes the uncertainties for large values of $Y$ and tends to optimize the fit for the small values of $Y$. To compensate for this trend, we used trial-anderror to modify equations (3) and (4). The constants of equations (3) and (4) were used as initial values, and the variance value for testing the goodness of fit should be determined from the unmodified equation (1). Then, we obtained the following attenuation equations,

$$
\begin{aligned}
& \text { Acceleration }\left(\mathrm{cm} \mathrm{sec}^{-2}\right): A=6.1476 R^{-1.6263} W^{1.0375}, \\
& \text { Velocity }\left(\mathrm{mm} \mathrm{sec}^{-1}\right): \quad V=3.5315 R^{-1.2664} W^{0.7836}
\end{aligned}
$$




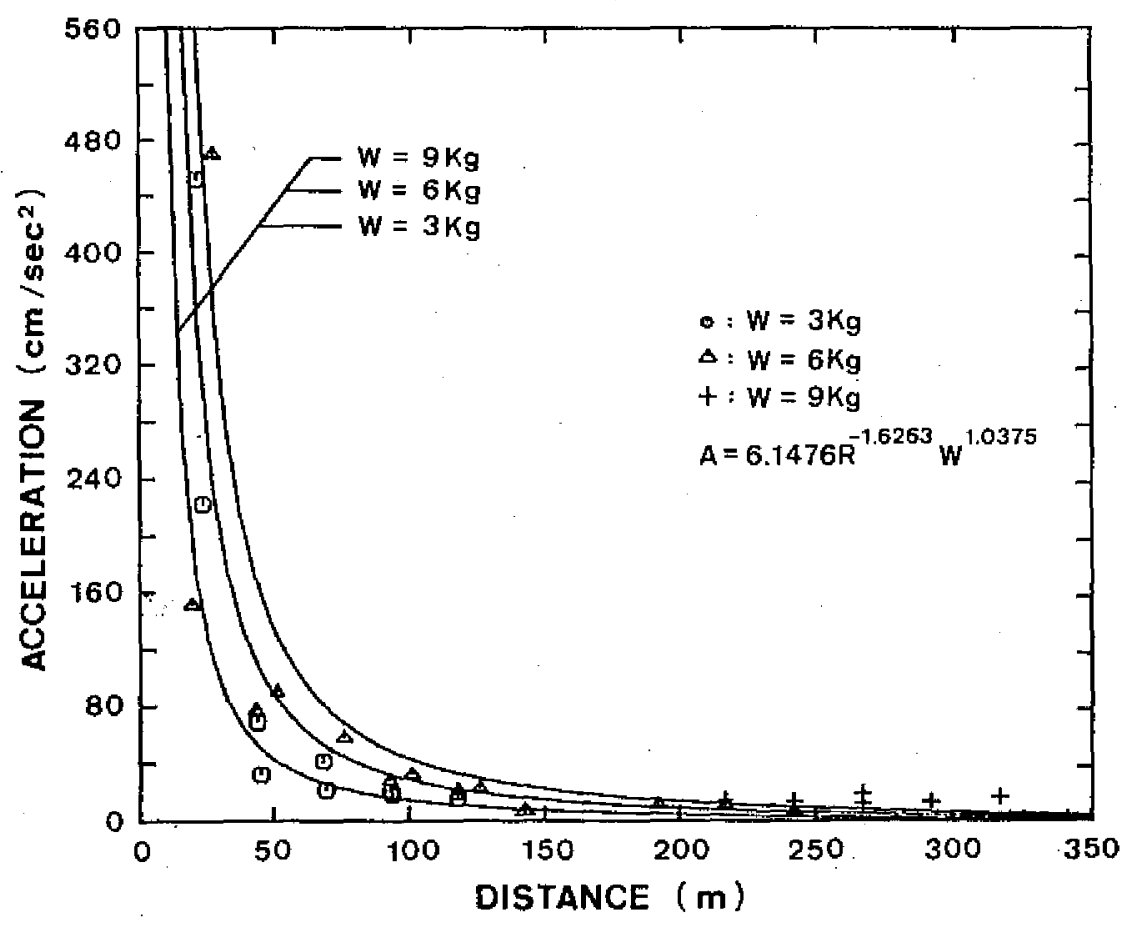

Fig. 9. Acceleration attenuation curves in the Peikang area.

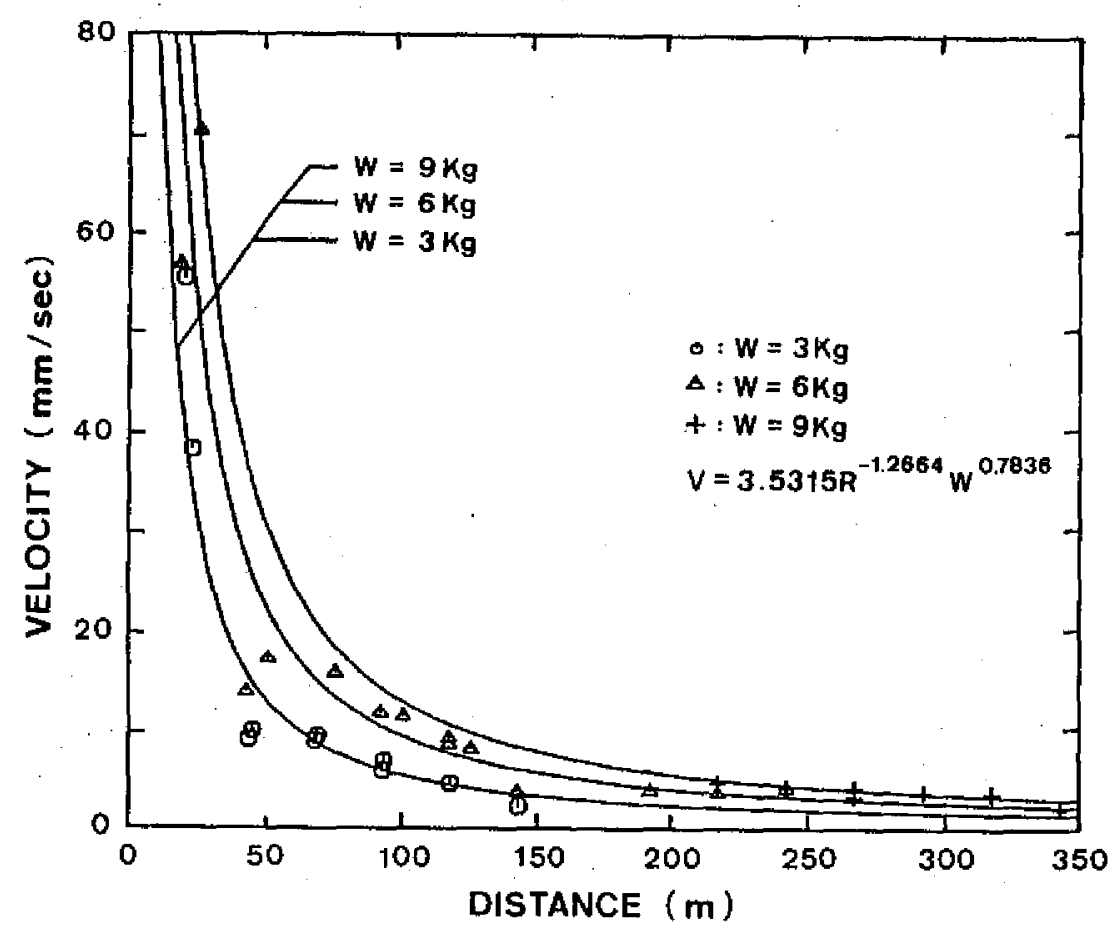

Fig. 10. Velocity attenuation curves in the Peikang area. 
The corresponding attenuation curves are shown in Figs. 9 and 10.

\section{DISCUSSION AND CONCLUSIONS}

Based on the time and frequency domain analysis of the ground motion records for the seven blasting experiments performed in the Peikang area, the principal results of this study are as follows:

1. From the time histories, we can see without difficultly that the amplitude of the ground motion is attenuated with distance, and is attenuated at a higher rate in the near field. In the meantime, there were large, low frequency ground motions after the high frequency wave's motion. From Table 2, we can find that most peaks occurred on the vertical component.

2. Based on the multiple linear regression of the observed peak ground motion values with different weights of explosive and hypocentral distances, we found that the attenuation equations for the Peikang survey area are:

Acceleration $\left(\mathrm{cm} \mathrm{sec}^{-2}\right): A=6.1476 R^{-1.6263} W^{1.0375}$,

Velocity $\left(\mathrm{mm} \mathrm{sec}^{-1}\right): \quad V=3.5315 R^{-1.2664} W^{0.7836}$,

where $W$ represents the weight of explosive in $g m$, and $R$ is the hypocentral distance in meters.

3. From the Fourier spectra, we know that the vibrational energy of the Peikang area is concentrated mainly on a frequency band lower than $10 \mathrm{~Hz}$. Except for this low frequency energy band, there was another energy band higher than $15 \mathrm{~Hz}$.

4. After comparison of the particle motions of these two frequency bands, we can see that the high frequency vibration, which is larger than $15 \mathrm{~Hz}$, is the body wave's motion that came from the blast source, and the low frequency vibration, which is lower than $10 \mathrm{~Hz}$, is mainly the surface wave's motion that was generated by the local geological structure.

Acknowledgements. The authors would like to thank Dr. Chi-Ching Liu for his valuable suggestions in this study. We are grateful to $\mathrm{Mr}$. Jui-Tun Chou, the seismic survey team of the Chinese Petroleum Corporation, and the technical staff of our institute for assistance in the field survey.

\section{REFERENCES}

Ang, A. H-S and W. H. Tang, 1975: Probability concept in engineering planning and design. V.1, Basic principles, Wiley, N. Y.

Chae, Y. S., 1978: Design of excavation blasts to prevent damage. Civil Engineering, 48, 4, 77-79.

Cooley, J. W. and J. W. Tukey, 1965: An algorithm for machine calculation of 
complex Fourier series. Mathematics of Computation, 19, 90, 297-301. Dowding, C. H., 1977: Ground-structure response to blasting vibration. Proceedings of the 14th Annual Meeting Society of Engineering Sciences, 1085-1093.

Duvall, W. I. and D. E. Fogelson, 1962: Review of criteria for estimating damages to residences from blasting vibrations. Bureau of Mines Report of Investigations, 5968 .

Medearis, K., 1977: Development of rational damage criteria for low-rise structures subjected to blasting vibrations. Proceedings of the 18th Symposium On Rock Mechanics, 1A2-1 1A2-6.

Naik, T. R., 1979: Preditions of damage to low-rise buildings due to ground vibrations created by blasting vibrations of concrete structures. SP-60, 259-264.

Northwood, T. D., R. Crawford, and A. T. Edwards, 1963: Blasting vibrations and building damage. The Engineer, 215, 5601, 973-978.

Shigekazu Uchiyama, Takuo Ohyama, and Fumio Kaneko, 1979: Characteristics of vibration by blasting. OYO Technical Report, 1, 55-74.

Wiss, J. F., 1981: Construction vibration : state-of-the-art. J. Geot. Eng. Div., 107, 167-181. 


\title{
北港地區爆炸引起的地表振動特性
}

\author{
温國樑 葉永田 \\ 中央研究院地球科學㸴究所
}

摘 要

近年来, 一般民彩非常注意在結構物附近進行炸測所引起之地表振動問題, 要減少或除 去災害, 須建立一可行的蕉則, 作䉆預先規劃和現場實施爆炸作業時之參考。1985 年 6 月 我們在北港地區實施七次炸測試驗, 由所收集人工爆炸引起的地表振動記錄, 觀察不同炸薬 量，不同距離的最大振動値，並推導最大地表振動的理椧袁減公式，其結果爲：

加速度 $\left(\mathrm{cm} / \mathrm{sec}^{2}\right): A=6.1476 \mathrm{R}^{-1.6263} \mathrm{~W}^{1.0375}$

速度 $(\mathrm{mm} / \mathrm{sec}): V=3.5315 R^{-1.2644} \mathrm{~W}^{0.7836}$

其中，W 代表炸藥量，單位爲克； $\mathrm{R}$ 代表震源距，單位爲公尺。

此外, 䉆瞭解炸測産生之振動頻率內涵, 我們也將炸測誡驗所記錄之地動加速度歷時, 經富氏轉換求出其富氏振幅譜。由此可知北港地區之振動能量集中於 10 赫以下和大於 15 赫之 頻帶。此高頻能帶爱爆炸震源産生, 而低頻能帶則䳕局 部地質之效應。另外, 由兩區質點振

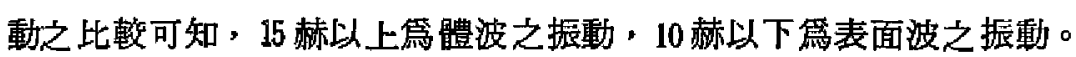


